DE GRUYTER GOSPODARKA SUROWCAMI MINERALNYMI - MINERAL RESOURCES MANAGEMENT

\title{
The development of the glass industry in central Vietnam
}

\section{Introduction}

The first development aid project designed by GET Company under the auspices of the Ministry of Industry and Trade of the Czech Republic was approved by the government for the period of 2006-2010 under the title "Acquisition of a raw material base for industrial use in the glass industry in the southern area of central Vietnam". Its main objective was to verify and to evaluate the sources of glass sands and of other minerals (feldspar, kaolin) for the development of the glass industry in Vietnam in prospective areas of the provinces of Thua Tien Hue, Quang Tri (over $300 \mathrm{~km}^{2}$ ) and Phu Tho (ca. $150 \mathrm{~km}^{2}$ ). Additionally, another objective was estimation of the resources of verified deposits in these areas (Spudil et al. 2009, 2010).

The geological works implemented led to the discovery of a commercially significant deposit of glass sands in the Phong Dién district in the province of Thua Tien Hué (more than 50 million tons of measured resources of a high quality quartz sand) and several po-

* Doc. Ing. Ph.D., VSB - Technical University of Ostrava, Faculty of Mining and Geology, e-mail: milan.mikolas@vsb.cz

** D.Sc. Eng., Silesian University of Technology, Gliwice.

*** Ing., GET Ltd. Prague, Czech Republic.

**** Ph.D., GET Ltd. Prague, Czech Republic.

***** Ing., VSB - Technical University of Ostrava, Faculty of Mining and Geology. 
tentially significant deposits of kaolin (in the Ha Hoá and Thanh Ba districts located in Phu Tho province).

In 2012-2014, for the Czech Development Agency, GET company implemented the new development project entitled "The Development of the Glass Industry in Central Vietnam", which builds on prior activities related to the international development aid provided by the Czech Republic. The main objective of this project is strengthening of the technical and professional skills of the partner organisations, i.e. the State Geological Survey and its locally relevant Division in Vinh City by means of the vocational training of local specialists and in the manner of the delivery of modern technical equipment. In addition article highlights economic potential of the local raw materials used for the production of a glass batch. The result was a definition of the three mineral sources of raw materials suitable for use in the glass industry: Phong Xuan (dolomitic limestone in the Phong Dien district), Thuong Quang (limestone in the Nam Dong district), and Bot Do (feldspar in the A Luoi district).

The Phong Xuan carbonate deposit is only $10 \mathrm{~km}$ distant from the deposit of silica sand and thereby constitutes an excellent resource base for the future glass factory in the Phong Dien industrial zone. At the deposit there is an estimated over 5 million tonnes of measured resources of limestone and dolomitic limestone (Tvrdý et al. 2013a).

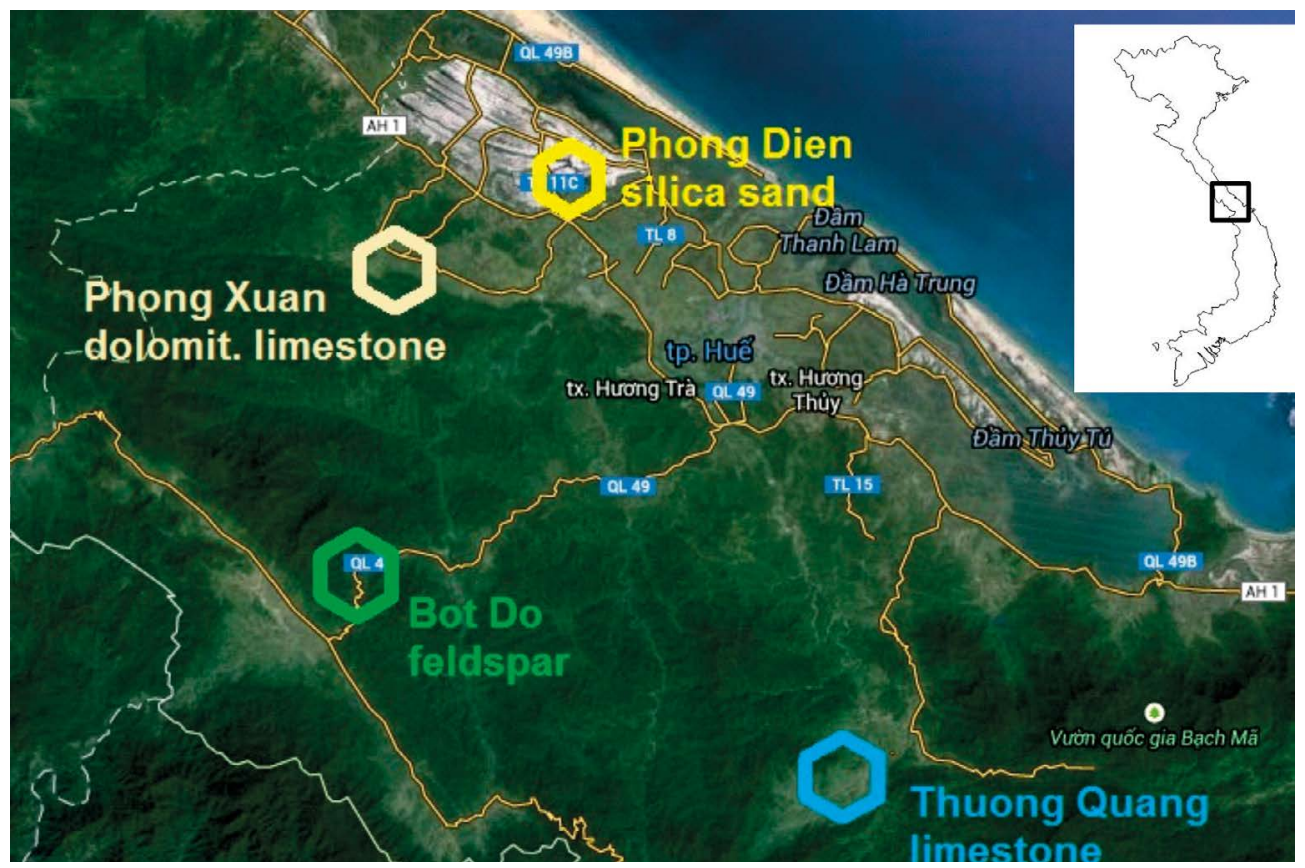

Fig. 1. Location of studied area. A satellite image of the Phong Dien silica sand deposit and the prospective areas for feldspar, dolomitic limestone and limestone

Rys 1. Lokalizacja analizowanego obszaru. Zdjęcie satelitarne złoża piasku krzemowego Phong Dien i przyszłych obszarów złóż skaleni, wapieni dolomitowych i wapieni 


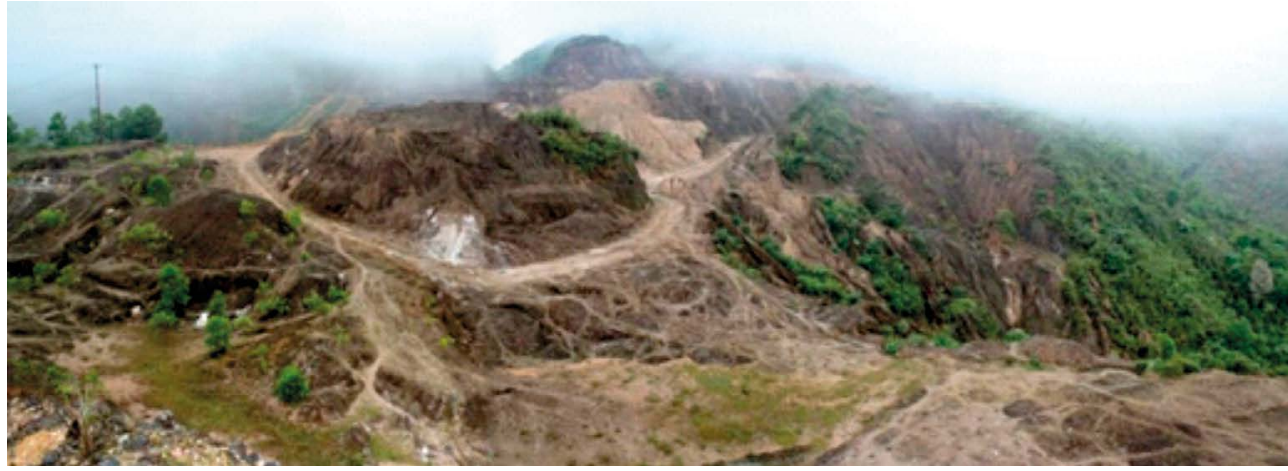

Fig. 2. The Bot Do kaolin and feldspar deposit

Rys. 2. Złoże kaolinu i skaleni Bot Do

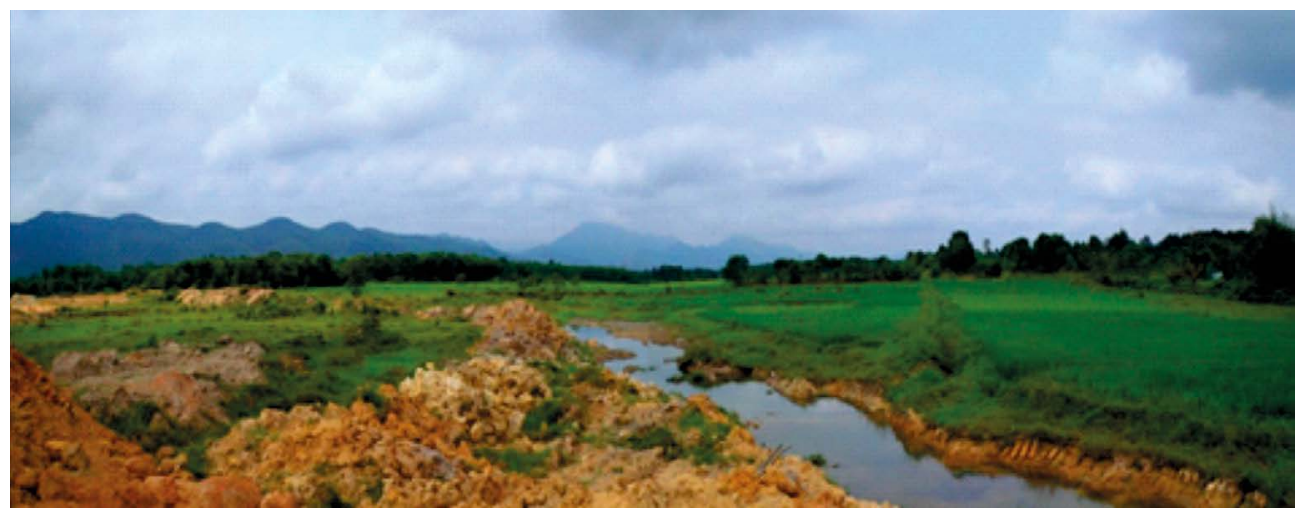

Fig. 3. The Phong Xuan dolomitic limestone deposit

Rys. 3. Złoże wapienia dolomitowego Phong Xuan

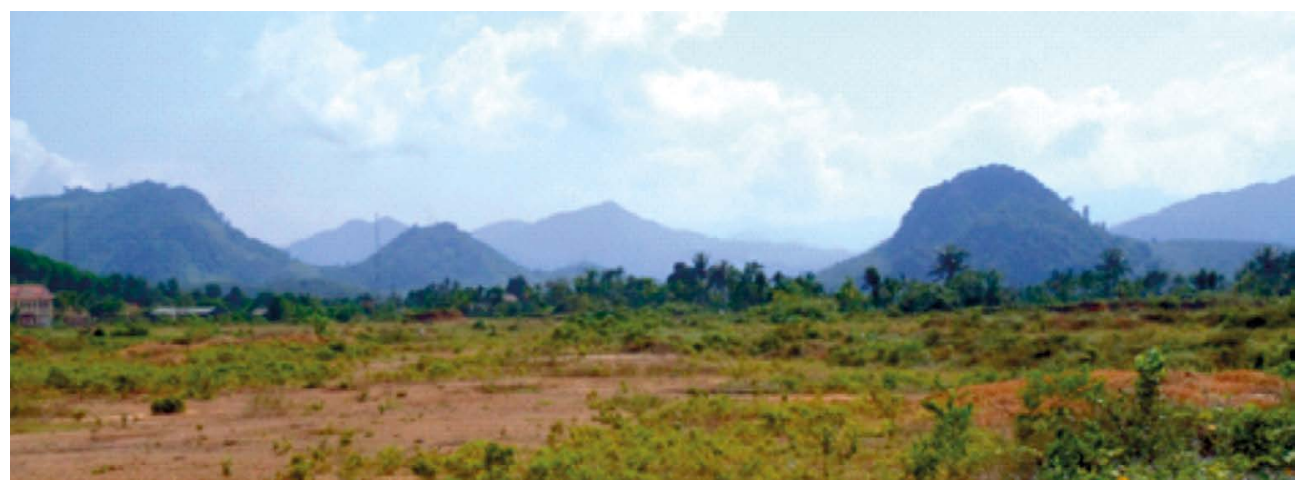

Fig. 4. The Thuong Quang limestone deposit

Rys. 4. Złoże wapienia Thuong Quang 
The limestone Thuong Quang deposit is located in Thuong Long-Thuong Quang district, about $40 \mathrm{~km}$ southeast of Hue. Carbonates are represented by weakly metamorphosed, dark to light gray carbonate Co Bai formations of Devoénian age. At the deposit there is estimated over 16 million tonnes of indicated resources of limestone (Tvrdý et al. 2013b).

Feldspar Bot Do deposit was searched in the border district of A Luoi, about $70 \mathrm{~km}$ west of Hue. The raw feldspar material is the bedrock of kaolin. It consists of leucocratic metaaplites of Dai Loc igneous complex (Tvrdý et al. 2013c).

\section{Technological research of raw materials suitable for the manufacture of glass batch}

The technological study of samples from deposits of raw materials in central Vietnam that are suitable for the manufacture of glass batch follows-up on work carried out previously, which comprised the indicative sampling and definition of reconnaissance mineral resources (2012), the detailed sampling and evaluation of deposits (2013) and additional field work (2014).

Implemented as part of the first activity was a detailed technological survey associated with the preparation of the glass material utilising a universal flux with a defined proportion of the independently tested samples of the selected raw material, including the evaluation of its whiteness, brightness, lightness and colorimetric characteristics. In this manner the suitability of the specific raw material was verified for the manufacture of glass material of varying clearness.

The second activity focused on optimising the composition of a glass batch using blended variant formulas, including firing glass material on a thick porcelain carrier plate, or as a thin layer of glass deposited on a plate. In addition to the verification of the flowability of the glass material, also determined were its whiteness, brightness, lightness and its colorimetric characteristics. The combining of the Vietnamese glass raw materials enables the optimisation of the manufacturing programme by focusing on different types of glass, including crystal glass on one hand and coloured glass forms on the other (Tvrdý and Pticen 2014).

\subsection{A detailed technological survey}

From the basic samples stored in the contractor's archive, blended samples were prepared in order to best characterise the individual types of raw materials from each of the deposits assessed. The basic samples and the blended samples assembled from amongst them are outlined in the following Table 1 . This set was additionally complemented by two samples from the Phong Dien glass sand deposit (Q12, Q2) and by a sample of feldspar newly collected at the Bot Do deposit (BD101-14). 
Table 1. List of the samples processed

Tabela 1. Wykaz przebadanych próbek

\begin{tabular}{|l|c|c|c|l|}
\hline \multirow{2}{*}{ Deposit } & \multicolumn{3}{c|}{ Number of samples } & \multirow{2}{*}{ Raw materials } \\
\cline { 2 - 4 } & basic & blended & reference & \\
\hline Phong Xuan & 11 & 3 & - & limestone, dolomitic limestone \\
\hline Thuong Quang & 28 & 5 & - & limestone, limestone with a dolomite admixture \\
\hline Bot Do & 10 & 3 & 1 & feldspar material \\
\hline Phong Dien & - & - & 2 & glass sand \\
\hline Total & 49 & 11 & 3 & \\
\hline
\end{tabular}

\subsubsection{The chemical composition of the materials selected}

Average chemical composition of the samples of the raw materials utilised to create the blended technological samples and characterising the verified deposits is presented in Table 2. The table clearly indicates the high quality of the glass sand Q12 $\left(\mathrm{Fe}_{2} \mathrm{O}_{3}\right.$ only 0.010 wt.\%), the feldspar (BD1) and also the limestone. In terms of their chemical composition the raw materials selected are comparable with the Czech resources that are utilised for glass manufacturing (Table 4).

\subsubsection{Characteristics of the glass material that was prepared from individual raw materials}

A basic comparison (see Figures 5-8) indicates that glass sand Q12 is comparable with the best Czech sand from Střeleč u Jičína (trademark ST15 or ST12 with a max. content of 0.015 or 0.012 wt. $\%$ of $\mathrm{Fe}_{2} \mathrm{O}_{3}$ ), while sodium-potassium feldspar BD1 is comparable with the Czech potassium feldspar from Halámky $\left(0.13\right.$ wt.\% of $\left.\mathrm{Fe}_{2} \mathrm{O}_{3}\right)$. The melt from blended samples of carbonates has a pale green colour; it is comparable, however, with the Czech limestone Čertovy schody D8. The exception is limestone TQ5 (Fig.8) with a dolomite admixture, the colour of the melt of which is rather dark green.

During the preparation of the borate glass discs in the fluxer it became evident that for forming the melt sodium-potassium feldspar BD1 is more advantageous than the "harder" and more viscous potassium feldspar of Czech provenance. Melting glass material in a platinum crucible is very intense and utilising controlled automatic cooling it was possible to create transparent discs that did not break and did not contain any inhomogeneities. The glass discs prepared vary between clear and coloured based on the chromatogenic elements that are present in the raw material tested $(\mathrm{Fe}, \mathrm{Ti}, \mathrm{Cr}$, etc.). 
Table 2. Chemical composition of the blended technological samples (wt. \%)

Tabela 2. Skład chemiczny sporządzonych próbek (\% wagowo)

\begin{tabular}{|c|c|c|c|c|c|c|c|c|c|c|}
\hline Deposit & Sample & $\mathrm{SiO}_{2}$ & $\mathrm{Al}_{2} \mathrm{O}_{3}$ & $\mathrm{Fe}_{2} \mathrm{O}_{3}$ & $\mathrm{TiO}_{2}$ & $\mathrm{CaO}$ & $\mathrm{MgO}$ & $\mathrm{K}_{2} \mathrm{O}$ & $\mathrm{Na}_{2} \mathrm{O}$ & $\begin{array}{l}\text { Loss on } \\
\text { ignition }\end{array}$ \\
\hline \multirow{2}{*}{ Phong Dien } & sand Q2 & 97.75 & 1.84 & 0.010 & 0.02 & 0.13 & 0.03 & 0.01 & 0.01 & 0.12 \\
\hline & sand Q12 & 99.59 & 0.16 & 0.068 & 0.09 & 0.02 & 0.01 & 0.01 & 0.01 & 0.10 \\
\hline \multirow{3}{*}{ Phong Xuan } & limestone PX1 & 0.44 & 0.13 & 0.060 & - & 53.20 & 2.28 & - & - & - \\
\hline & $\begin{array}{l}\text { dolomitic } \\
\text { limestone PX2 }\end{array}$ & 0.75 & 0.13 & 0.060 & - & 43.30 & 10.51 & - & - & - \\
\hline & $\begin{array}{l}\text { dolomitic } \\
\text { limestone PX3 }\end{array}$ & 3.44 & 0.28 & 0.140 & - & 38.24 & 13.35 & - & - & - \\
\hline \multirow{5}{*}{ Thuong Quang } & limestone TQ1 & 1.39 & 0.35 & 0.240 & - & 54.08 & 0.64 & - & - & - \\
\hline & limestone TQ2 & 2.87 & 0.51 & 0.350 & - & 53.64 & 0.54 & - & - & - \\
\hline & limestone TQ3 & 1.68 & 0.40 & 0.250 & - & 53.41 & 0.71 & - & - & - \\
\hline & limestone TQ4 & 3.24 & 0.86 & 0.540 & - & 52.15 & 0.95 & - & - & - \\
\hline & $\begin{array}{l}\text { limestone with } \\
\text { a dolomite } \\
\text { admixture TQ5 }\end{array}$ & 4.88 & 0.63 & 0.930 & - & 47.84 & 3.88 & - & - & - \\
\hline \multirow{3}{*}{ Bot Do } & feldspar BD1 & 74.60 & 15.60 & 0.130 & 0.03 & 0.83 & 0.08 & 2.98 & 4.49 & 0.53 \\
\hline & feldspar BD2 & 70.22 & 19.98 & 0.290 & 0.03 & 0.74 & 0.29 & 1.82 & 4.02 & - \\
\hline & feldspar BD3 & 67.11 & 22.54 & 0.500 & 0.05 & 0.72 & 0.31 & 2.83 & 2.17 & - \\
\hline
\end{tabular}

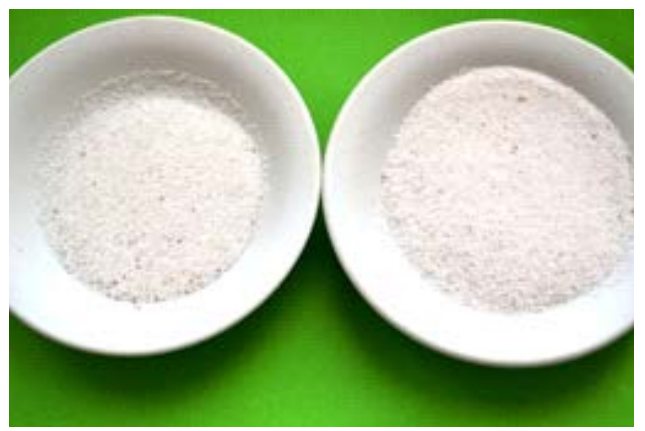

Fig. 5. Calcined feldspars BD1 and Halámky Rys. 5. Wypalony skaleń BDI i Halanka

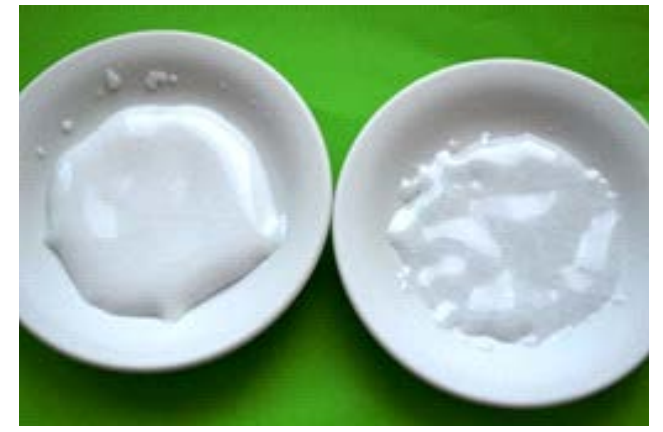

Fig. 6. Calcined sands Q12 and ST15 Rys. 6. Wypalony piasek Q12 i ST15 


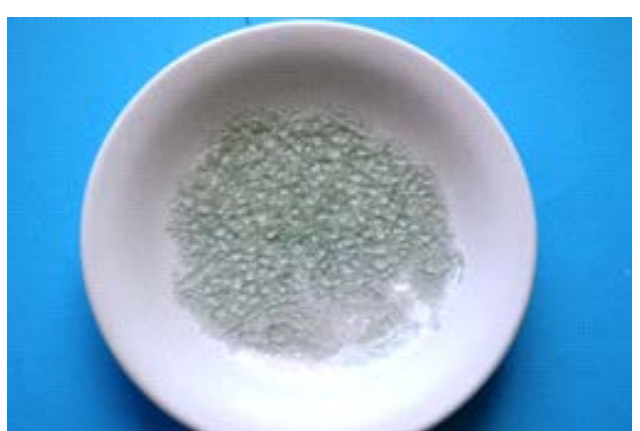

Fig. 7. Calcined limestone D8 Čertovy schody

Rys. 7. Wypalony wapień D8 Čertovy schody

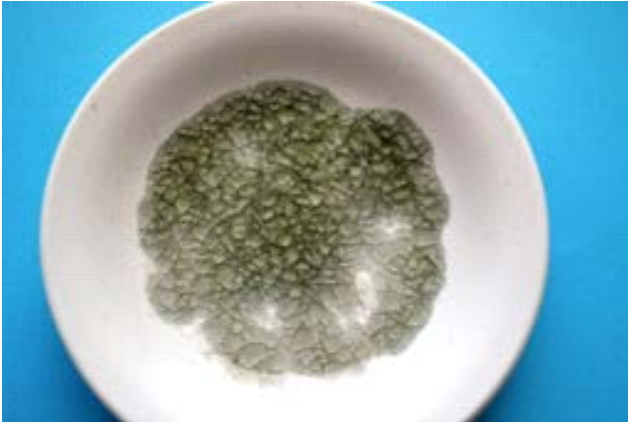

Fig. 8: Calcined limestone with a dolomite

Rys. 8. Wypalony wapień z dolomitem

Table 3. Colorimetric parameters of the created glass compared against a white PTFE background (measured with a gloss)

Tabela 3. Parametry kolorymetryczne wytworzonych szkieł na białym teflonie PTFE (pomiary połysku)

\begin{tabular}{|c|c|c|c|c|c|c|c|}
\hline \multirow{2}{*}{ Deposit } & \multirow{2}{*}{ Sample } & \multirow{2}{*}{$\begin{array}{c}\text { Whiteness } \\
\text { R457 } \\
{[\%]}\end{array}$} & \multirow{2}{*}{$\begin{array}{c}\text { Brightness } \\
\text { Ry } \\
{[\%]}\end{array}$} & \multirow{2}{*}{$\begin{array}{l}\text { Lightness } \\
\text { L }\end{array}$} & \multicolumn{2}{|c|}{$\begin{array}{l}\text { Colorimetric } \\
\text { characteristics }\end{array}$} & \multirow{2}{*}{$\begin{array}{c}\text { Overall } \\
\text { Yellownes } \\
\mathrm{Y}_{\mathrm{e}} / \mathrm{DIN}\end{array}$} \\
\hline & & & & & $\mathrm{a}^{*}$ & $b^{*}$ & \\
\hline \multirow{2}{*}{$\begin{array}{l}\text { Phong } \\
\text { Dien }\end{array}$} & sand Q12 & 79.3 & 78.4 & 90.98 & 0.09 & 0.67 & -1.29 \\
\hline & sand Q2 & 79.0 & 78.3 & 90.93 & 0.06 & -0.54 & -1.04 \\
\hline \multirow{3}{*}{$\begin{array}{l}\text { Phong } \\
\text { Xuan }\end{array}$} & limestone PX1 & 79.7 & 79.1 & 91.26 & 0.06 & -0.54 & -1.04 \\
\hline & $\begin{array}{l}\text { dolomitic limestone } \\
\text { PX2 }\end{array}$ & 79.3 & 78.6 & 91.06 & 0.06 & -0.55 & -1.05 \\
\hline & $\begin{array}{l}\text { dolomitic limestone } \\
\text { PX3 }\end{array}$ & 80.9 & 80.2 & 91.76 & 0.07 & -0.56 & -1.18 \\
\hline \multirow{5}{*}{$\begin{array}{l}\text { Thuong } \\
\text { Quang }\end{array}$} & limestone TQ1 & 77.6 & 77.4 & 90.52 & -0.23 & -0.02 & -0.22 \\
\hline & limestone TQ2 & 75.8 & 76.2 & 89.96 & -0.39 & 0.53 & 0.75 \\
\hline & limestone TQ3 & 77.4 & 77.6 & 90.58 & -0.39 & 0.33 & 0.34 \\
\hline & limestone TQ4 & 74.9 & 76.6 & 90.13 & -0.89 & 1.79 & 2.86 \\
\hline & $\begin{array}{l}\text { limestone with a olom. } \\
\text { admixture TQ5 }\end{array}$ & 70.4 & 74.2 & 88.99 & -1.36 & 3.89 & 6.68 \\
\hline \multirow{3}{*}{ Bot Do } & feldspar BD1 & 79.5 & 78.9 & 91.20 & -0.06 & -0.42 & -0.89 \\
\hline & feldspar BD2 & 78.5 & 78.4 & 90.96 & -0.21 & 0.05 & -0.08 \\
\hline & feldspar BD3 & 77.1 & 77.4 & 90.49 & -0.37 & 0.42 & 0.55 \\
\hline
\end{tabular}


The glass material was prepared using two glass sands, Q12 and Q2, from the Phong Dien area. Sand Q12 has a higher degree of whiteness, brightness and lightness and a lower yellowness index than sand Q2. Therefore it is more suitable for inclusion in the formula for glass batch.

Limestone PX1 (Phong Xuan) is of a very high quality, providing glass material with a whiteness of 79.7\%, high brightness and lightness. Despite its higher $\mathrm{Fe}_{2} \mathrm{O}_{3}$ content (0.14 wt.\% in comparison with 0.06 wt.\% in PX1 and PX2 samples) dolomitic limestone PX3, with a brightness of $80.9 \%$ and the lowest yellowness index $(-1.18)$, appears to be a superior ingredient for the glass material than dolomitic limestone PX2 providing glass material with a lower whiteness $(79.3 \%)$, brightness and lightness.

In regard to glass material, the limestone from the Thuong Quang area has lower quality than does the raw material of the PX series. The blended sample of limestone TQ1 has the highest whiteness (R457 nm 77.6\%) while also of a similar to slightly lower quality is limestone TQ3, with whiteness of 77.4, while lower still is TQ2 (whiteness 75.8\%), etc. In this series limestone TQ4 is the poorest in quality with a whiteness of its glass material of $74.9 \%$ and with a highly elevated overall yellowness index (2.86). Limestone TQ5, with a dolomite admixture, is the very worst, however; it provides glass material with whiteness of only $70.4 \%$ and it also has a very high chromaticity index (overall yellowness Ye/DIN 6.68). Colorimetric measurement of the limestone and the dolomite in glass material, together with chemical analysis, may provider good guidance for determining the usability of raw materials in the glass industry (for crystal,flat glass, container and coloured glass).

The purity and the composition of the feldspar (induced by better fused sodium materials) are distinct after they have been melted in the glass material. Sodium-potassium feldspar BD1 manifests high quality with whiteness $\mathrm{R} 457 \mathrm{~nm}$ of $79.5 \%$ and a reduced overall

Table 4. Chemical composition of the raw materials utilised in the Czech glass industry (wt.\%)

Tabela 4. Skład chemiczny materiałów wsadowych wykorzystywanych w przemyśle szklarskim w Czechach

\begin{tabular}{|l|c|c|c|c|c|c|c|c|c|}
\hline \multicolumn{1}{|c|}{ Raw material } & $\mathrm{SiO}_{2}$ & $\mathrm{Al}_{2} \mathrm{O}_{3}$ & $\mathrm{Fe}_{2} \mathrm{O}_{3}$ & $\mathrm{TiO}_{2}$ & $\mathrm{CaO}$ & $\mathrm{MgO}$ & $\mathrm{K}_{2} \mathrm{O}$ & $\mathrm{Na}_{2} \mathrm{O}$ & $\begin{array}{c}\text { Loss on } \\
\text { ignition }\end{array}$ \\
\hline Sand Střeleč ST15 & 98.80 & 0.80 & 0.015 & 0.02 & 0.08 & 0.03 & 0.01 & 0.01 & 0.13 \\
\hline Limestone Čertovy schody D8 & 0.08 & 0.15 & 0.08 & 0.00 & 55.78 & 0.35 & 0.15 & 0.02 & 43.39 \\
\hline $\begin{array}{l}\text { Dolomite Zlaté Moravce } \\
\text { (Slovakia) }\end{array}$ & 0.01 & 0.01 & 0.01 & 0.00 & 31.61 & 22.20 & 0.20 & 0.01 & 45.97 \\
\hline $\begin{array}{l}\text { Potassium feldspar Halámky } \\
\text { Ž75K13 }\end{array}$ & 70.96 & 15.87 & 0.13 & 0.03 & 0.27 & 0.09 & 11.00 & 1.31 & 0.36 \\
\hline \begin{tabular}{l} 
Kaolin Sedlec Ia Božičany \\
\hline
\end{tabular} & 47.30 & 36.70 & 0.85 & 0.17 & 0.35 & 0.24 & 0.95 & 0.02 & 13.40 \\
\hline
\end{tabular}


yellowness (e.g. parameter $b^{*}-0.42$, i.e. Ye -0.89 ). Exactly in accordance with expectations the quality of the glass material decreases in feldspar BD2 (sodium feldspar Ž45Na30) and is lowest in the poorest quality and highly contaminated feldspar BD3 with a whiteness of $77.1 \%$ in the glass material and with an overall yellowness of 0.55 .

The results of the tests of blended samples suggest that most suitable for utilisation in the formulas for glass batch are: glass sand Q12, feldspar BD1, limestone PX1, dolomitic limestone PX3 or PX2 and limestone TQ1.

\subsection{Proposals for the composition of the glass batch formulas}

\subsubsection{The development of formulas}

As part of the project, 10 glass batch formulas were compiled. These formulas were prepared on the basis of the established Czech standards, in order to assess the potential impact of Vietnamese raw materials on the character of the glass material.

For the comparison of Vietnamese raw materials there was created an experimental technological sample from Czech raw materials that are commonly used in the manufacture of glass (the sample does not match with the real composition of the glass batch, where the shards and other additives are added).

Table 5 defines the composition of the experimental formulas, which, in comparison with the technological standard formula (STD - Formula No. 1), are based on a combination of selected Vietnamese raw materials. Formula No. 7, apart from its moderate content of the binding washed kaolin, is an exclusively Vietnamese composition, i.e. it contains no calcined or washed kaolin and no aluminium oxide $\mathrm{Al}_{2} \mathrm{O}_{3}$. Formula No. 8 is the least chemically pure and it contains sand Q2, poor quality and more contaminated feldspar BD3 and the poorest quality limestone with dolomite admixture TQ5. Formulas Nos. 9 and 10 contain feldspar BD1-14 collected in 2014.

\subsubsection{Characteristics of the material in the glass discs and on the carrier plates}

The results of the colorimetric measurement of the glass discs prepared in accordance with formulas Nos. 1, 2 and 8 are listed in table 6. This table indicates that against the white PTFE, as a background for the transparent thin glass material, formulas No. 1 (technoligical standard) and No. 2 are very similar and are in the spectrum of a light green colour, while glass material prepared in accordance with formula No. 8, with a higher content of colouring oxides, is already in a light yellow colour spectrum.

After melting finely ground glass mixtures in a rapid-firing tunnel kiln (oxidation-reduction firing at $1380^{\circ} \mathrm{C}$ for 7.5 hours) glass materials with a smooth and glossy surface were obtained. The vast majority of glass materials utilised are comparable to those of the 
Table 5. Formulas compiled for the experimental glass batch (batch materials in wt.\%)

Tabela 5. Zestawienie eksperymentalnych receptur szkła (dawki surowców w \% wagowo)

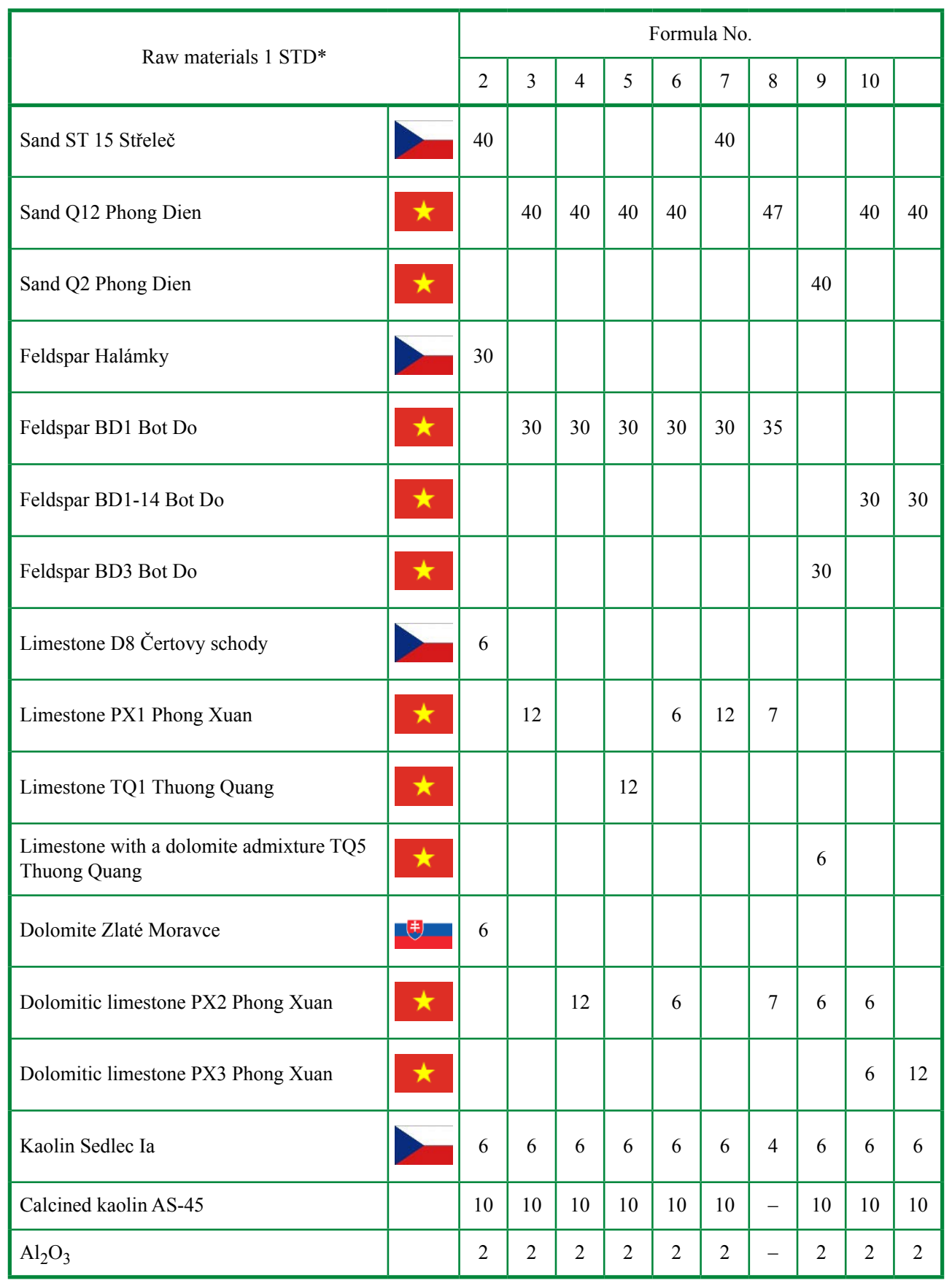

* Technological standard prepared from Czech raw materials. 
Table 6. Colorimetric characteristics of the glasses, prepared in accordance with formulas Nos. 1, 2 and 8 (measured with a gloss against white PTFE)

Tabela 6. Kolorymetryczne parametry szkieł przygotowanych według receptur o numerach 1, 2 i 8 (pomiary połysku na białym PTFE)

\begin{tabular}{|c|c|c|c|c|c|c|c|}
\hline \multirow{3}{*}{$\begin{array}{c}\text { Formula No. } \\
1\end{array}$} & \multirow{3}{*}{$\begin{array}{c}\text { Whiteness } \\
\text { R457 } \\
{[\%]} \\
78.6\end{array}$} & \multirow{3}{*}{$\begin{array}{c}\text { Brightness } \\
\text { Ry } \\
{[\%]}\end{array}$} & \multirow{3}{*}{$\begin{array}{c}\text { Lightness L } \\
90.90\end{array}$} & \multicolumn{2}{|c|}{ Chromaticity } & \multirow{2}{*}{\multicolumn{2}{|c|}{$\begin{array}{c}\text { Overall Yellowness } \\
\mathrm{Y}_{\mathrm{e}} / \mathrm{DIN}\end{array}$}} \\
\hline & & & & \multirow{2}{*}{$\frac{a^{*}}{-0.08}$} & \multirow{2}{*}{$\frac{b^{*}}{-0.21}$} & & \\
\hline & & & & & & -0.50 & Green \\
\hline 2 & 78.1 & 77.82 & 90.70 & -0.10 & -0.12 & -0.32 & Green \\
\hline 8 & 77.0 & 77.37 & 90.49 & -0.39 & 0.50 & 0.69 & Yellow/Amber \\
\hline
\end{tabular}

standard Czech formula, with the exception of formula No. 3 and 7, which produced cracks in the glass material (known as a krakele effect) which are caused by an insufficient content of $\mathrm{Al}_{2} \mathrm{O}_{3}$, the usual bearers of which are raw materials (i.e. calcined kaolin and alumina) that have not been included in this formula. At a temperature of $1380^{\circ} \mathrm{C}$ the flowability of the glass material was $1-3 \mathrm{~cm}$.

Photographic documentation of the transparent glass material lying in a thick layer on a porcelain carrier plate is provided in Figures 9-13.

\subsubsection{The chemical composition of the experimental glass batch}

Formula No. 1 is Czech and contains potassium feldspar from Halámky, whereas all the other formulas contain sodium-potassium feldspar BD1 or poor sodium to sodium-potassium feldspar BD3 and therefore they have a different content of alkalis.

Formula No. 8 contains sand Q2, poor feldspar BD3 and the least pure limestone TQ5 with a dolomite admixture. Formulas Nos. 9 and 10 contain feldspar BD1-14 collected in 2014, which probably contains more sodium and is more contaminated with colouring oxides than the original sodium-potassium feldspar BD1.

Formula No. 7 essentially comprises only Vietnamese raw materials without $\mathrm{Al}_{2} \mathrm{O}_{3}$ or calcined kaolin, but with a minimum content of washed kaolin Sedlec Ia.

The chemical composition of the glass batch prepared in accordance with these formulas is listed in Table 7.

\subsubsection{Flowability of glass}

In addition to measuring the colorimetric properties of the glass material also verified was the extent of the flowability of the glass in the heat after its melting. The photographic documentation in Figure 14 shows the varying speed of the flowability of the glass at a temperature of ca. $1400^{\circ} \mathrm{C}$. Specifically in formulas Nos. 9 and 10 that utilised sodium potassium feldspar BD1-14 that was collected this year its higher speed of flowability is evident 


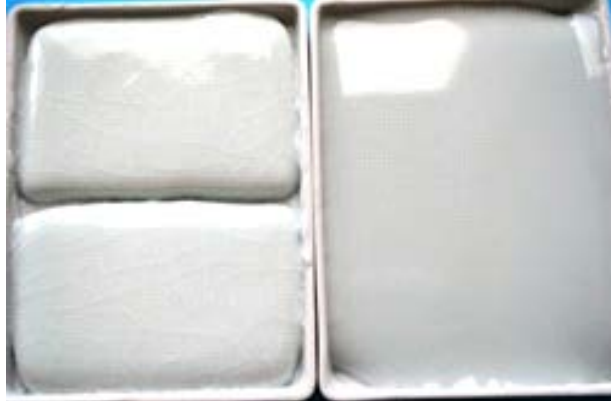

Fig. 9. Formulas No. 1 and 2

Rys. 9. Receptury nr 1 i 2

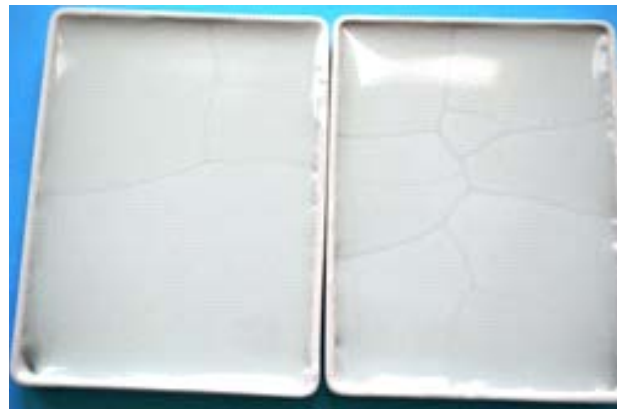

Fig. 11. Formulas No. 5 and 6

Rys. 11. Receptury nr 5 i 6

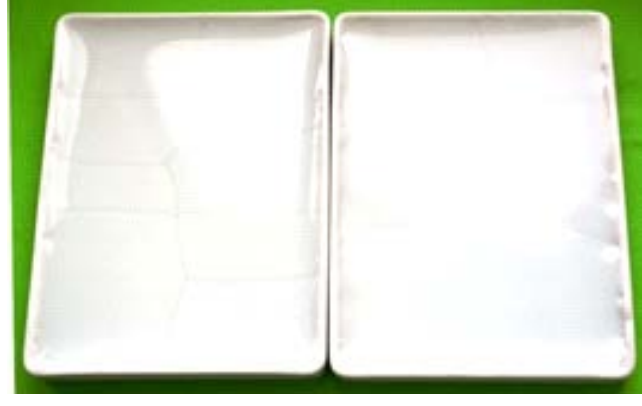

Fig. 10. Formulas No. 3 and 4

Rys. 10. Receptury nr 3 i 4

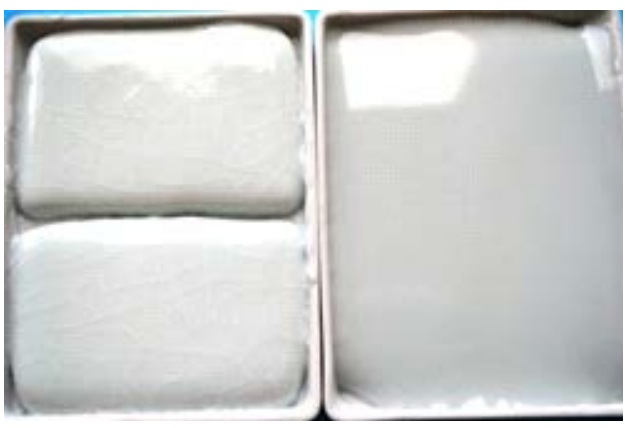

Fig. 12. Formulas No. 7 and 8

Rys. 12. Receptury nr 7 i 8

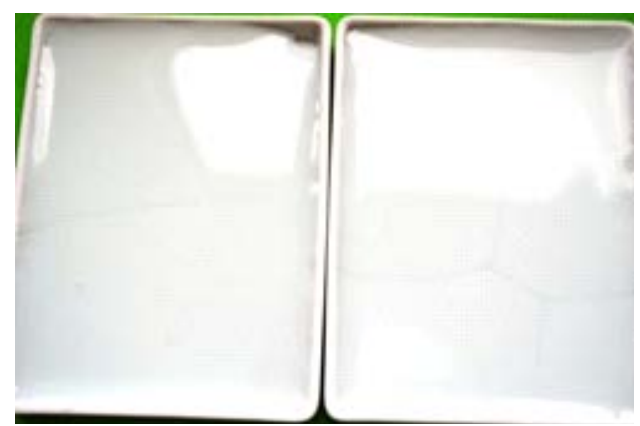

Fig. 13: Formulas No. 9 and 10

Rys. 13. Receptury nr 9 i 10 
Table 7. Chemical composition of the glass batch prepared in accordance with their individual formulas (wt.\%)

Tabela 7. Skład chemiczny szkieł sporządzony zgodnie z ich indywidualnymi recepturami (\% wagowo)

\begin{tabular}{|c|c|c|c|c|c|c|c|c|c|c|}
\hline \multirow{2}{*}{ Indicator } & \multicolumn{9}{|c|}{ Formula No. } \\
\cline { 2 - 12 } & $1 \mathrm{STD}$ & 2 & 3 & 4 & 5 & 6 & 7 & 8 & 9 & 10 \\
\hline $\mathrm{SiO}_{2}$ & 69.80 & 71.10 & 71.10 & 71.30 & 71.00 & 71.00 & 75.50 & 70.10 & 69.70 & 69.40 \\
\hline $\mathrm{Al}_{2} \mathrm{O}_{3}$ & 12.95 & 11.93 & 11.91 & 11.83 & 11.87 & 11.90 & 5.69 & 13.49 & 13.22 & 13.19 \\
\hline $\mathrm{Fe}_{2} \mathrm{O}_{3}$ & 0.16 & 0.16 & 0.15 & 0.17 & 0.15 & 0.15 & 0.09 & 0.34 & 0.36 & 0.33 \\
\hline $\mathrm{TiO}_{2}$ & 0.05 & 0.05 & 0.05 & 0.05 & 0.05 & 0.05 & 0.02 & 0.06 & 0.10 & 0.09 \\
\hline $\mathrm{CaO}^{2}$ & 5.33 & 6.61 & 5.64 & 7.04 & 6.24 & 6.76 & 7.22 & 6.00 & 5.36 & 5.01 \\
\hline $\mathrm{MgO}_{\mathrm{K}} \mathrm{O}$ & 1.24 & 0.44 & 1.29 & 0.09 & 0.85 & 0.44 & 0.92 & 0.98 & 1.58 & 1.77 \\
\hline $\mathrm{Na}$ & 3.57 & 1.86 & 1.81 & 1.83 & 1.82 & 1.81 & 1.80 & 1.68 & 1.88 & 1.89 \\
\hline Loss on ignition & 6.19 & 6.34 & 6.47 & 6.18 & 6.41 & 6.35 & 6.95 & 6.40 & 6.40 & 6.40 \\
\hline
\end{tabular}

and thereby there is also a lower viscosity of the melt due to its higher content of the sodium component in comparison with the potassium feldspar utilised in standard formula No. 1 or with the "Vietnamese" formula No. 7, i.e. without the addition of calcined kaolin or $\mathrm{Al}_{2} \mathrm{O}_{3}$ and with a high content of $\mathrm{SiO}_{2}$ (differing in comparison with the other formulas by cca. a 4.5 wt.\%). The above example suggests that it is possible to correct the viscosity of the molten glass material by ensuring the suitable composition of the glass batch.

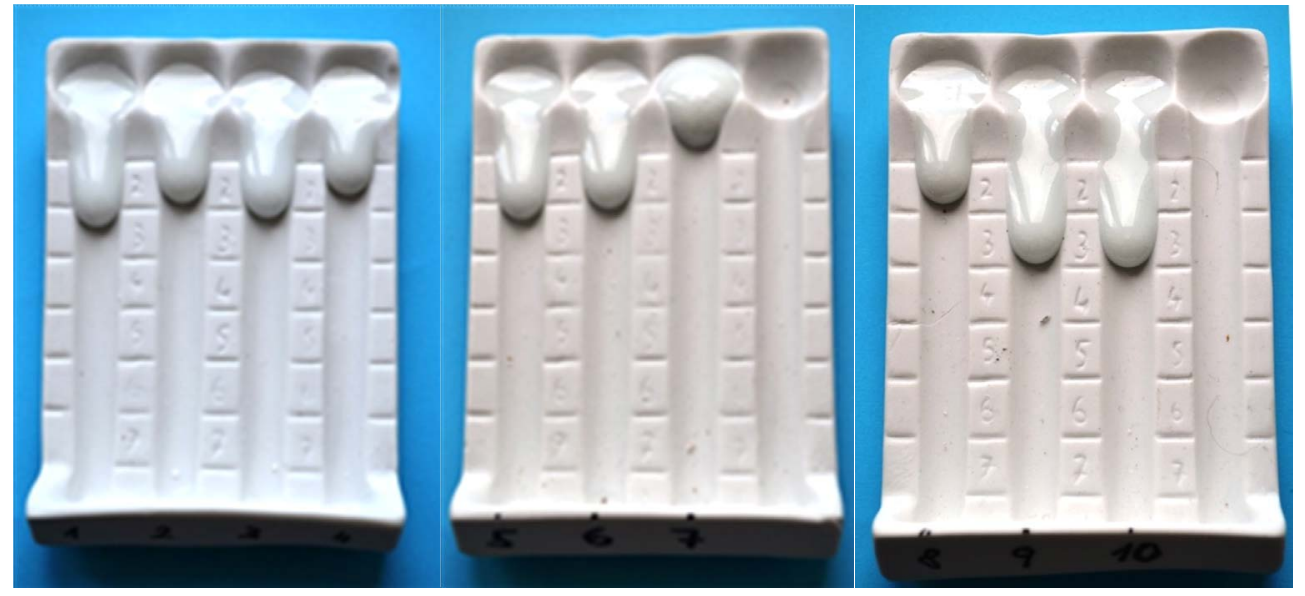

Fig. 14. Flowability of glass prepared in accordance with 10 formulas

Rys. 14. Płynność szkła określona dla 10 receptur 


\subsubsection{Colouring the glass material by the addition of a pigment}

As part of the technological testing, the colouring of the glass material by adding suitable pigments was implemented. For example, a yellowish ("Ivory") colour is achieved by adding $\mathrm{MnCO}_{3}$, while grey-green glass material is the result of the addition of $\mathrm{Zr}-\mathrm{Si}-\mathrm{Co}-\mathrm{Fe}-\mathrm{Cr}$ compounds and the pigment that tints glass material with shades of blue is dominated by Co- Zn-Al-Si compounds, whereas the raspberry red colour is based on $\mathrm{Zr}-\mathrm{Si}$-S-Cd-Se elements and black is resultant on an admixture of such metallic elements as $\mathrm{Co}-\mathrm{Ni}-\mathrm{Fe}$ and $\mathrm{Cr}$.

The resultant colouration of the glass material by a thick layer is influenced not only by the dosage of the added pigment, but also by the temperature and the oxidation-reduction atmosphere in the kiln.

The photographic documentation of examples of glass produced from Vietnamese raw materials and coloured using commercially available additives is in Figures 15-17 while the colorimetric parameters are listed in Table 9.

\subsubsection{The characteristics of molten glass in a thick layer on a carrier plate}

Table 8 lists the results of the colorimetric measurements of transparent glass material in a thick layer $(\mathrm{ca} .1 \mathrm{~cm})$ on a porcelain carrier plate. The results of the colorimetric measurements correlate reasonably well with the chemical analysis of the glass batch.

Table 8. Colorimetric parameters of transparent glass material in a thick layer on a carrier plate (measured with a gloss)

Tabela 8. Parametry kolorymetryczne grubych płyt szkła przeźroczystego (pomiary połysku)

\begin{tabular}{|c|c|c|c|c|c|c|}
\hline \multirow{2}{*}{$\begin{array}{c}\text { Formula } \\
\text { No. }\end{array}$} & \multirow{2}{*}{$\begin{array}{c}\text { Whiteness R } 457 \\
{[\%]}\end{array}$} & \multirow{2}{*}{$\begin{array}{c}\text { Brightness Ry } \\
{[\%]}\end{array}$} & \multirow{2}{*}{$\begin{array}{c}\text { Lightness } \\
\text { L }\end{array}$} & \multicolumn{2}{|c|}{ Chromaticity } & \multirow{2}{*}{$\begin{array}{c}\text { Overall yellowness } \\
\text { Ye/DIN }\end{array}$} \\
\hline & & & & $a^{*}$ & $b^{*}$ & \\
\hline 1 & 65.50 & 66.11 & 85.05 & -3.75 & 0.79 & -1.49 \\
\hline 2 & 67.79 & 68.32 & 86.17 & -3.65 & 0.68 & -1.62 \\
\hline 3 & 68.50 & 69.00 & 86.51 & -3.50 & 0.65 & -1.56 \\
\hline 4 & 63.85 & 65.28 & 84.63 & -3.39 & 1.54 & 0.37 \\
\hline 5 & 67.59 & 68.22 & 86.12 & -3.50 & 0.77 & -1.31 \\
\hline 6 & 65.85 & 66.84 & 85.42 & -3.28 & 1.09 & -0.46 \\
\hline 7 & 72.37 & 73.89 & 88.87 & -3.54 & 1.49 & 0.15 \\
\hline 8 & 62.50 & 64.42 & 84.18 & -3.62 & 2.15 & 1.47 \\
\hline 9 & 65.61 & 66.50 & 85.25 & -3.96 & 1.09 & -1.03 \\
\hline 10 & 65.59 & 66.59 & 85.30 & -3.91 & 1.19 & -0.77 \\
\hline
\end{tabular}




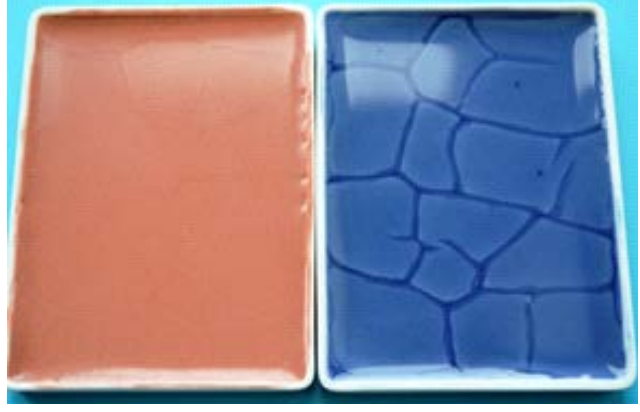

Fig. 15. Red (Zr-Si-Cd-S-Se) - blue (Co-Zn-Al-Si) Rys. 15. Czerwony (Zr-Si-Cd-S-Se) niebieski (Co-Zn-Al.-Si)

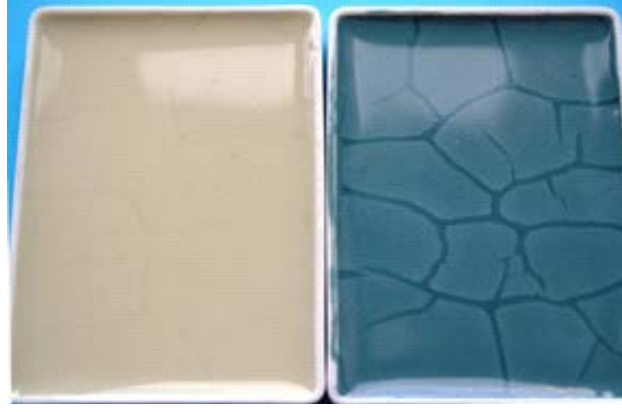

Fig. 16. Ivory $\left(\mathrm{MnCO}_{3}\right)$ - grey-green $(\mathrm{Zr}-\mathrm{Si}-\mathrm{Co}-\mathrm{Fe}-\mathrm{Cr})$ Rys 16. Kość słoniowa (MnCo3) ciemnozielony (Zr-Si-Co-Fe-Cr)

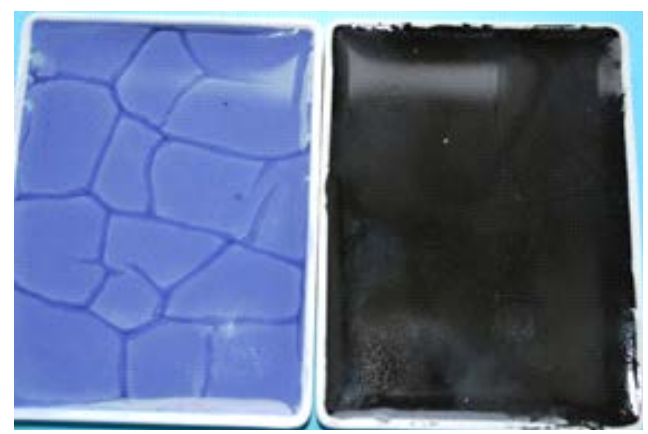

Fig. 17. Blue (Co-Zn-Al-Si) - black (Co-Ni-Fe-Cr)

Rys. 17. Niebieski (Co-Zn-Al.-Si) - czarny (Co-Ni-Fe-Cr)

Table 9. Colorimetric parameters of coloured glass material in a thick layer on a carrier plate (measured with a gloss)

Tabela 9. Parametry kolorymetryczne grubych płyt szkła kolorowego (pomiary połysku)

\begin{tabular}{|c|c|c|c|c|c|c|}
\hline \multirow{2}{*}{ Formula } & \multirow{2}{*}{$\begin{array}{c}\text { Whiteness R } \\
457 \\
{[\%]}\end{array}$} & \multirow{2}{*}{$\begin{array}{c}\text { Brightness Ry } \\
{[\%]}\end{array}$} & \multirow{2}{*}{$\begin{array}{c}\text { Lightness } \\
\text { L }\end{array}$} & \multicolumn{2}{|c|}{ Chromaticity } & \multirow{2}{*}{$\begin{array}{c}\text { Overall yellowness } \\
\text { Ye/DIN }\end{array}$} \\
\hline & & & & $a^{*}$ & $\mathrm{~b}^{*}$ & \\
\hline Ivory & 39.70 & 50.20 & 76.19 & -2.77 & 13.47 & 26.22 \\
\hline Grey-green & 19.81 & 18.08 & 49.59 & -7.04 & -3.67 & -21.39 \\
\hline Blue & 18.74 & 10.92 & 39.45 & 6.57 & -22.46 & -98.54 \\
\hline Raspberry red & 14.70 & 22.93 & 55.00 & 23.91 & 16.89 & 75.58 \\
\hline Black & 4.41 & 4.53 & 25.34 & -0.03 & 0.62 & 3.13 \\
\hline
\end{tabular}


The highest whiteness, R $457 \mathrm{~nm}(72.4 \%)$, is that of glass material No. 7, without the addition of any washed and calcined kaolin which brings with it the highest content of the colouring oxides $\mathrm{Fe}_{2} \mathrm{O}_{3}$ and $\mathrm{TiO}_{2}$ (formula No. 7 also has the lowest content of colouring oxides, only a 0.09 wt.\% of $\mathrm{Fe}_{2} \mathrm{O}_{3}$ and a $0.02 \mathrm{wt} . \%$ of $\mathrm{TiO}_{2}$ ), likewise brightness and lightness, though the overall yellowness index is relatively elevated (Ye 0.15).

Most effective in terms of the yellow colouring of glass is formula No. 2 (Ye -1.62) with a content of $\mathrm{Fe}_{2} \mathrm{O}_{3}$ in the glass batch of 0.16 wt.\%, while the poorest (i.e. the most yellow), in accordance with expectations, is glass material No. 8 (Ye 1.47) with a high content of colouring oxides in the glass batch $\left(0.34\right.$ wt.\% of $\left.\mathrm{Fe}_{2} \mathrm{O}_{3}\right)$ and the lowest content of $\mathrm{Na}_{2} \mathrm{O}$. Formulas Nos. 9 and 10 are probably more contaminated by the newly delivered feldspar BD1-14 and, in comparison with formulas Nos. 2, 3 and 5, have lower whiteness R $457 \mathrm{~nm}$ (by cca. $2 \%$ ) and a higher degree of yellow tinting.

Table 9 lists the parameters of coloured glass, from which it is evident a dramatically different colour of glass in a thick layer that is expressed using the CIELAB coordinates. The hue and the saturation of colours can be adjusted by simply adding a dose of pigment to the glass batch.

\section{Selection of the most suitable formula for the glass batch}

Based on the tests of the raw materials that were implemented and the compositions that were prepared, here we list the recommended proportion of raw materials of Vietnamese origin in the formula for a glass batch. Any future production will probably not be

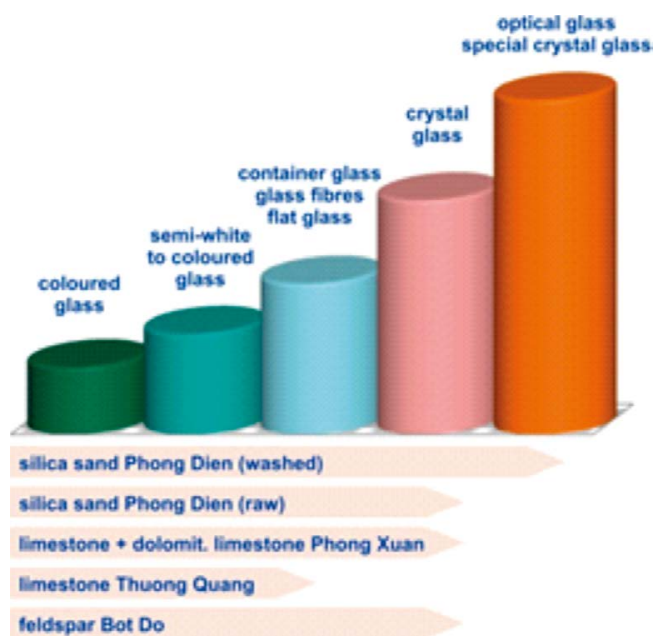

Fig. 18. The possible use, based on concentration of iron, of the silica sand, the limestone and the feldspar from the Thua Thien Province for different glass industry products (Tvrdý et al. 2014)

Rys. 18. Zastosowanie różnych przemysłowych produktów szklanych opartych na koncentracjach żelaza, krzemionki, wapienia i skalenia z prowincji Thua Thien (Tvrdý i in. 2014) 
able to avoid the use of additional commercial materials, either as a standard constituent of a glass batch or as a correction component in order to modify the properties of the input mixture.

Specific formulas for the preparation of a glass batch will also depend on the intended scope of production. In accordance with all the tests carried out so far during the three-year duration of the "Development of the Glass Industry in Central Vietnam" project the raw materials evaluated can all be used for the intensive production of crystal glass, sheet glass all the way to white or coloured container glass (see Fig. 18).

\section{Conclusion}

Implemented in the context of the Project for Foreign Development Aid "Development of the Glass Industry in Central Vietnam" was testing the preparation of glass from the characteristic raw materials of the verified deposits in the Thua Thien Hue Province. In addition to the optimisation of the glass batch, detailed technological research was also implemented with the goal of achieving the full utilisation of Vietnamese raw materials for the manufacture of high quality glass. The production programme may be varied-focusing not only on the purest crystal type glass, but also on sheet and container glass and even coloured glass.

Based on the results achieved it can be concluded that, when treated properly, the glass sand from the Phong Dien deposit with its content of a $0.010 \mathrm{wt} . \%$ of $\mathrm{Fe}_{2} \mathrm{O}_{3}$ is fully comparable with the best Czech glass sand ST15 or, after its magnetic separation, it is purer than even the best sand ST12 with a maximum content of iron oxide of $0.012 \mathrm{wt} . \%$. Silica sand is perfectly treatable and also, in terms of its grain size, it is reminiscent of the sand from the area of Střeleč. In terms of the production planned the sand from the Phong Dien deposit represents a basic glass-forming raw material. In accordance with the tests that were carried out its optimal proportion in a glass batch is ca. $40-70 \%$, depending on the volume of recycled glass (cullet) in the formula.

Natural, usually untreated sodium-potassium to sodium feldspar from the Bot Do deposit represents high-quality raw material, which is easily treatable by magnetic separation and may, in addition to high-quality silica sand, also comprise a base for the glass batch and the ceramic mixtures, including a highly pure transparent vitreous glaze. Its content in the real glass batch can reach up to $10 \%$. One potential problem may be the relatively small-scale of the reserves of these raw materials (less than 200,000 tons) and it will therefore be necessary to search for additional sources. As a stabiliser, feldspar can be suitably complemented by kaolin from the same deposit area, the high quality of which has also been verified during the previous works.

Selected limestones of the PX1 type and the dolomitic limestone PX3 from the Phong Xuan deposit also featured as a technologically pleasant surprise. Although in their natural state they are dark in colour, they do have the purity necessary for the production of glass 
material. The Phong Xuan deposit is also only $10 \mathrm{~km}$ distant from the deposit of silica sand and thereby constitutes an excellent resource base for the future glass factory in the Phong Dien industrial zone. The carbonate raw material from the Phong Xuan deposit is suitable for inclusion in the formula in an amount up to approx. 15\%. It should be noted that even better carbonates were verified in other provinces of Vietnam during our earlier work (Bezuško et al. 2011).

On the contrary, limestone raw material from the Thuong Quang deposit belongs amongst the rather poorer materials and it is therefore primarily applicable to formulas for producing coloured, semi-white and partly also white container glass.

\section{REFERENCES}

Bezuško et al. 2011 - Bezuško, P., Bong, T.C., Ho, L.Q., Chrobok, I., Lhotský, P., Medvíd', D., Thoang, N.V., Svatý, V. and Vrána, O. 2011. Evaluation of the use of Vietnamese marble and limestone for the glass industry. Progress report on the project in the year 2010: "Acquisition of the raw material base for industrial use in the glass and ceramic industry in the southern part of Central Vietnam", GDGMV Hanoi.

Tvrdý, J. and Pticen, F. 2014. Report concerning the technological research of raw materials suitable for the manufacture of glass batch. GDGMV Hanoi.

Tvrdý et al. 2013a - Tvrdý, J., Ječný, M., Pticen, F., Brož, B., Soukup, D., Tran, C.B., Spudil, J. and Pechar, T. 2013a Final Report Phong Xuan (Thua Thien Hue Province, Vietnam). Raw Material: Limestone for the Glass Industry. Project for Foreign Development Aid of the Czech Republic "Technical Assistance and Capacity Building on Technological Evaluation of some Industrial Minerals to be used as Stabilizers and Flux for Glass Industry in Thua Thien Hue Province", GDGMV Hanoi.

Tvrdý et al. 2013b - Tvrdý, J., Ječný, M., Pticen, F., Brož, B., Soukup, D., Tran, C.B., Spudil, J. and Pechar, T. 2013b. Final Report Thuong Quang (Thua Thien Hue Province, Vietnam). Raw Material: Limestone for the Glass Industry. Project for Foreign Development Aid of the Czech Republic "Technical Assistance and Capacity Building on Technological Evaluation of some Industrial Minerals to be used as Stabilizers and Flux for Glass Industry in Thua Thien Hue Province", GDGMV Hanoi.

Tvrdý et al. 2013b - Tvrdý, J., Ječný, M., Pticen, F., Brož, B., Soukup, D., Tran, C.B., Spudil, J. and Pechar, T. 2013c. Final Report Bot Do (Thua Thien Hue Province, Vietnam). Raw Material: Feldspar. Project for Foreign Development Aid of the Czech Republic "Technical Assistance and Capacity Building on Technological Evaluation of some Industrial Minerals to be used as Stabilizers and Flux for Glass Industry in Thua Thien Hue Province", GDGMV Hanoi.

Tvrdý et al. 2014 - Tvrdý, J., Pechar, T. and Lhotský, P. 2014. Výsledky projektu zahraniční rozvojové spolupráce „Rozvoj sklářského průmyslu ve středním Vietnamu“ (The results of the international development cooperation project entitled The Development of the Glass Industry in Central Vietnam). The Newsletter of the Czech Union of Geological Associations, 18, 84-86. [Online] Available at: http://www.caig-uga.cz/attach/zpravodaj-uga-18-10-2014-178.pdf [Accessed: 15.01.2017].

Spudil et al. 2009 - Spudil, J., Bezuško, P., Brož, B., Jaček, M., Ječný, M., Koroš, I., Kunzová, L., Lhotský, P., Nekl, M., Michalík, B., Moravec, E., Volf, M. and Vrána, O. 2009. Final Report Phong Dién (Province Thua Thien Hue), Vietnam. Raw Material: Silica sand, GDGMV Hanoi.

Spudil et al. 2010 - Spudil, J., Bezuško, P., Brož, B., Jaček, M., Kunzová, L., Lhotský, P., Michalík, B., Tichovská, M. and Vrána, O. 2010. Supplement No. 1A to the Final Report Phong Dién (Province Thua Thien Hue), Vietnam. Raw material: Silica sand, GDGMV Hanoi. 


\title{
ROZWÓJ PRZEMYSLU SZKLARSKIEGO W CENTRALNEJ CZĘŚCI WIETNAMU
}

\author{
Słowa kluczowe
}

Wietnam, skaleń, piasek kwarcowy, wapień i wapień dolomitowy, karbonatyzacja, przemysł szklarski

\section{Streszczenie}

Współczesne społeczeństwo charakteryzuje się funkcjonalną infrastrukturą oraz wystarczającą liczbą i różnorodnością materiałów w postaci różnych technicznych dóbr. Te wszystkie osiąnnięcia cywilizacyjne są nie tylko rezultatem ludzkich zdolności, ale również źródeł materialnych opartych na przemysłowych złożach minerałów. Ta grupa minerałów zawiera szeroki zakres naturalnych surowców, które są stosowane w wielu działach przemysłu. W ich skład wchodzą surowce stosowane do produkcji szkła, ceramiki lub wypełniaczy.

W 2014 roku ukończono trzyletni międzynarodowy projekt badawczy zatytułowany: „Rozwój przemysłu szklarskiego w centralnej części Wietnamu”. Celem projektu było znalezienie odpowiednich źródeł surowców mineralnych niezbędnych do produkcji szkła na bazie wcześniej sprawdzonych złóż piasku szklanego Phong Dien. Prace wykonano dla Czeskiej Agencji Rozwoju przez firmę GET Company z Pragi. Oprócz przeprowadzonej optymalizacji gatunków szkła, wykonano również szczegółowe badania technologiczne w celu pełnego wykorzystania wietnamskich surowców do produkcji wysokiej jakości szkła. Program produkcji szkła może być wieloraki, skoncentrowany nie tylko na najczystszym szkle typu kryształ, ale również na szkle płaskim (szyby), szkle gospodarczym i nawet szkle kolorowym.

\section{THE DEVELOPMENT OF THE GLASS INDUSTRY IN CENTRAL VIETNAM}

\author{
Keywords \\ Vietnam, feldspar raw material, quartz sand, limestone and dolomitic limestone, \\ carbonate rocks, glass industry
}

Abstract

A modern society is characterized by functional infrastructure and sufficient number and variety of materials in the form of various technical goods. All these civilization achievements are not only the result of human skills, but their material principles are based on industrial minerals. This group of materials includes a wide range of the natural raw materials which are used in many industries. This includes the raw materials for the manufacture of glass, ceramics or fillers.

In 2014 was complete three-year international development aid project under the title "The Development of the Glass Industry in Central Vietnam". The aim of the project was to find suitable 
sources of raw materials in formulations for glass production based on previously proven Phong Dien deposit of glass sand. Works carried out for the Czech Development Agency the GET Company from Czech Republic, Prague. In addition to the optimisation of the glass batch, detailed technological research was also implemented with the goal of achieving the full utilisation of Vietnamese raw materials for the manufacture of high quality glass. The production programme may be varied - focusing not only on the purest crystal type glass, but also on flat glass and container glass and even coloured glass. 